\title{
Model Pembelajaran Kooperatif dengan Presentasi Dapat Meningkatkan Kemampuan Belajar Administrasi Perkantoran (Menguraikan Karakteristik Administrasi Perkantoran)
}

\author{
Neneng Zuariah \\ zuariahn@gmail.com
}

\begin{abstract}
This study aims to determine efekifitas use cooperative learning model presentation can improve learning outcomes. Introduction to Office Administration, with the material characteristics Elaborating on the class $X$ of Office Administration in SMK Negeri AP 1 SMK 48 2016. The study was conducted in August until October 2016, at SMK Negeri 48 Jakarta. Learning Model for this use is the type cooperative presentation, Class Action Research, which consists of two cycles, each cycle held three meetings and at the third meeting done Post Test. Research has reached the indicators that are expected in the second cycle, the number of students who get the value up to the limit completely or by $97,46 \%$, and the average value reached 80 to $79 \%$ Presentation Mastery students have achieved indicator is expected in this study. It can be said that student achievement has increased by using model Learning It can be concluded that by applying the procedure cooperative learning model proper presentation, can improve learning outcomes administrative offices with basic introductory material characteristics Outlines Administration in Class X AP 1 SMK Negeri 48 Jakarta in 2016.
\end{abstract}

Keywords: Model Cooperative Learning, Learning Achievement, Characteristic Administration office 


\section{PENDAHULUAN}

Seperti kita ketahui bersama bahwa siswa bidang keahlian administrasi perkantoran mempunyai peran penting dalam memiliki keterampilan tentang Prinsip Administrasi Perkantoran dalam berbagai penyelenggaraan aktivitas perkantoran yang ada dalam dunia kerja di dunia usaha dan dunia Industri dalam meningkatkan daya saing pada era globalisasi dan era zaman teknologi.

Prosedur administrasi perkantoran merupakan suatu rangkaian metode yang telah menjadi pola tetap dalam melakukan suatu pekerjaan yang merupakan suatu kebulatan. Sementara itu prosedur perkantoran atau sistem perkantoran dalam melaksanakan suatu pekerjaan .

Dalam rangka pelaksanaan 8

Standar Nasional Pendidikan tentang

Standar Kompetensi Kelulusan untuk SMK Negeri 48 Jakarta, bidang keahlian administrasi perkantoran dalam rangka memenuhi permintaan dunia kerja, perlu adanya pengembangan diri dalam bidang keterampilan kompetensi keahlian produktifadministrasi perkantoran yaitu mampu dan trampil dalam penyelengaraan administrasi perkantoran. Untuk itu peneliti sebagai guru bidang keahlian administrasi perkantoran merasa tergerak untuk mengembangkan diri siswa dalam bidang kemampuan dan keterampilan kompetensi sekretaris bidang keahlian administrasi perkantoran dalam menyelengarakan administrasi perkantoran SMK Negeri 48 Jakarta perlu mempersiapkan dan mengkondisikan serta mengoptimalkan siswa administrasi perkantoran kelas $X$ AP1 untuk menyiapkan siswa dalam mengikuti praktek kerja industri, menyiapkan siswa administrasi perkantoran sesuai standar kebutuhan berdasarkan jumlah dan kualifikasi baik dari pembelajaran kompetensi penyelenggaraan dasar -dasar administrasi perkantoran menuangkan prakarsa, kreativitas, dan kemandirian sesuai dengan bakat, minat, dan perkembangan fisik serta psikologis siswa.Penyelenggaraan Pengantar Dasar Administrasi Perkantoran termasuk salah satu mata pelajaran Keterampilan Produktif bagi siswa Administrasi perkantoran kelas X AP
1 pada Bidang Keahlian Administrasi Perkantoran.

Nilai prestasi kompetensi Pengantar Dasar Administrasi Perkantoran,di kelas $X$ AP 1. rendah yaitu rata-rata 55 dibawah KKM, adapun KKM Pengantar Administrasi Perkantoran di sekolah Peneliti adalah 75.

Berdasarkan masalah diatas, maka Peneliti akan melakukan Penelitian Tindakan Kelas ( PTK ) dengan menerapkan Model Pembelajaran Kooperatif TipePresentasi dalam pembelajarankompetensi

PengantarDasar -dasar Administrasi Perkantoran . Diharapkan dengan penerapan model pembelajaran tersebut diatas dapat meningkatkan prestasi belajar dan keaktifan para siswa dalam belajar.

Tujuan yang ingin dicapai dalam penelitian tindakan kelas ini adalah :

Untuk mengetahui efektifitas penggunaan model pembelajaran Kooperatif tipe. Presentasi dalam meningkatkan hasil belajar siswa pada pelajaran Kompetensi Pengantar Dasar - dasar Administrasi Perkantoran khususnya tentang materi pokok Melakukan Komunikasi Kantor dan Menata Ruang Kantor di Kelas $X \quad$ AP 1. Bidang Keahlian Administrasi Perkantoran Semester Ganjil Tahun 2014/2015. Dalam meningkatkan hasil belajar kompetensi.

\section{Hasil Belajar}

Proses belajar yang dialami oleh siswa menghasilkan perubahanperubahan : dalam bidang pengetahuan atau pemahaman, dalam bidang keterampilan, dalam bidang nilai, dan sikap. Adanya perubahan itu tampak dalam belajar yang dihasilkan oleh siswa terhadap pertanyaan, persoalan, tugas yang diberikan oleh guru. Prestasi belajar itu berbeda-beda sifatnya, tergantung dari bidang yang didalamnya murid memberikan prestasi, misalnya dalam bidang pengetahuan / pemahaman (bidang kognitif).

Kompetensi andalan bidang keahlian administrasi perkantoran ini yaitu pengantar administrasi perkantoran, merupakan bagian dari ilmu yang memiliki karakteristik keterampilan yang sama dengan kompetensi Produktif administrasi perkantoran dengan lainnya.

Untuk Siswa Administrasi Perkantoran Khususnya kelas $\mathrm{X}$ AP.1. Dalam mempelajari dan 
mengembangkan

kompetensi

pengantar administrasi perkantoran digunakan metode Kooperetif Tipe Presentasi. Oleh karena itu, para Administrator harus mampu melakukan kerja ilmiah dalam menyelesaikan masalah atau mencari jawaban permasalahan - permasalahan yang dihadapi. Di suatu kantor dan organisasi apapun bidangnya.

Model pembelajaran Kooperatif dikembangkan untuk mencapai setidaktidaknya tiga tujuan penting pembelajaran, yaitu hasil belajar akademik, penerimaan terhadap keragaman, dan pengembangan keterampilan. Pembelajaran kooperatif, merupakan model pembelajaran dengan siswa bekerja dalam kelompok yang memiliki kemampuan heterogen.

Pembelajaran yang menggunakan model Kooperatif memiliki ciri-ciri sebagai berikut: siswa bekerja dalam kelompok secara Kooperatif untuk menyelesaikan materi belajar,kelompok dibentuk dari siswa yang memiliki kemampuan tinggi, sedang dan rendah,jika mungkin, anggota kelompok berasal dari ras, budaya, suku, jenis kelamin yang berbedabeda,penghargaan lebih berorientasi pada kelompok dari pada individu. Evaluasi atau memberikan umpan balik. Memberikan

Mengajarkan penghargaan. keterampilan kerjasama dan kolaborasi. Keterampilan ini penting karena banyak anak muda dan orang dewasa masih kurang dalam keterampilan sosial.

Keterampilan-keterampilan Sosial Keterampilan Berbagi, Keterampilan Berperan Serta, Keterampilanketerampilan Komunikasi, PembangunanTim, Keterampilanketerampilan Kelompok.

Kegiatan Penelitian Tindakan Kelas ini menitik beratkan pada peningkatan hasil belajar siswa dalam mengikuti kompetensi Pengantar Administrasi Perkantoran yang terintegrasi dari pelajaran produktifAdministrasi Perkantoran yang harus dimiliki siswa kelas AP 1 di SMK Negeri 48 Jakarta.

Berdasarkan kajian pustaka di atas, maka dalam penelitian ini dapat diambil hipotesis tindakan sebagai berikut :Pembelajaran dengan menggunaan model pembelajaran Kooperatif tipe Presentasi dapat meningkatkan prestasi belajar siswa pada pembelajaran Produktif Administrasi Perkantoran "Pengantar
Dasar Administrasi Perkantoran" dikelas X AP 1 SMK Negeri 48 Jakarta Tahun 2014/-2015.

Untuk itu peneliti ingin menciptakan tenaga SDM yang berkwalitas terutama siswa $X$ AP 1 , untuk benar -benar menjadi tenaga kerja yang dibutuh kan dalam suatu kantor.

Penelitian ini dilaksanakan di SMK Negeri 48 Jakarta, Semester Ganjil Tahun Pelajaran 2016 - 2017 subyek penelitian dalam PTK ini adalah siswa kelas X AP 1. SMK Negeri 48 Jakarta.

Materi yang diajarkan adalah Standar Kompetensi (SK)1, yaitu: Siswa dapat memahami Prinsipprinsip Pengantar

Administrasi Perkantoran .Kompetensi.Menata Ruang Kantor Administrasi Perkantoran ,danKompetensi Dasar.

Penelitian ini adalah penelitian tindakan kelas (action research) yang terdiri dari dua siklus dan tiap siklus terdiri dari empat tahap, yaitu perencanaan, pelaksanaan tindakan, pengamatan dan refleksi. Penelitian akan dilanjutkan pada siklus berikutnya jika tindakan yang diberikan belum mencapai indikator yang diharapkan.

Rencana Penelitian dimulai minggu ke 4 bulan Juli s/d minggu ke 6 bulan November 2016. Guru memintasiswa untuk berpikir secara berempat/berlima (berkelompok) untuk menjawab pertanyaan yang terdapat dalam LKS1. Jawaban di tulis pada Lembar Jawaban yang disiapkan.

Meminta wakil kelompok menjawab pertanyaan yang terdapat pada LKS 1siswa melaksanakan diskusi kelas dalam menjawab masalah/pertanyaan yang terdapat pada LKS 1.

Memberi penguatan dari hasil diskusi kelas (contoh dalam memberikan penguatan pada konsep-konsep penting dapat dilihat pada materi essensial)

Membimbing siswa menyusun Kesimpulan. Menugaskan kepada siswa membuat laporan Penyelenggaraan Aktivitas Administrasi Perkantoran secara simulasi di lab Administrasi Perkantoran dengan foto hasil pengamatan.

Menulis topik yang akan dipelajari yaitu Simulasi Menyelenggarakan Aktivitas Administrasi Perkantoran 
dan Menata ruang dalam simulasi Kantor Kecil .

Menyebutkan tujuan pembelajaran yang harus dicapai dalam belajar Membagikan LKS 1 yang berisi pertanyaan tentang materi Indentifikasi Penyelenggaraan administrasi Perkantoran dalam Kantor kecil secara Simulasi. Meminta siswa untuk berpikir secara individu untuk menjawab pertanyaan yang terdapat dalam LKS. Jawaban di tulis pada Lembar Jawaban. penguatan pada konsep-konsep penting dapat dilihat pada materi essensial) Membimbing siswa menyusun kesimpulan.

Menugaskan siswa melakukan wawancara Kesebuah Kantor DU/DI Bagaimana Tata Cara Dalam Penyelengaraan Aktivitas Kegiatan -kegiatan administrasi Perkantoran dan Tata Cara Menyusun Ruang Kantor Modern.

Setelah mendapatkan penjelasan penguatan dari guru mata pelajaran, pada minggu ke tiga siklus 2 diadakan post test/ evaluasi prestasi belajar siswa. Gunanya untuk mengetahui seberapa jauh pemahaman siswa terhadap materi KompetensiPengantar Administrasi Perkantoran yang telah disampaikan melalui pembelajaran Model Kooperatif tipe Presentasi.

Dari hasil pengamatan pada siklus 1, peneliti menemukan keberhasilan dan kegagalan dari tindakan yang diberikan.Implikasi dari tindakan pertama yakni menguji keaktifan siswa dalam membaca materi pelajaran, berpikir menjawab pertanyaan sendiri, berdiskusi dengan teman pasangannya, dan berdiskusi dalam kelas, terlihat kesungguhan dari beberapa siswa yang dapat mengerjakan LKS dengan cepat dan benar.Walaupun masih banyak siswa yang kurang sungguh-sungguh yang ditandai dengan tidak bisa menjawab pertanyaan pada LKS, pada pertemuan ke dua siswa sudah mulai sungguh-sungguh dan mengerjakan pertanyaan-pertanyaan pada LKS dapat dijawab dengan benar. Ini berarti siswa sudah dapat memahami apa yang di diskusikan bersama.

Untuk melihat sejauh mana keefektifan proses pembelajaran dengan model Kooperatif tipe Presentasi , pada penelitian ini digunakan dua jenis teknik pengumpulan data, yaitu observasi dan tes. Instrumen yang digunakan adalah lembar observasi perilaku siswa dan lembar tertulis berupa pos test. Observasi yang akan dilakukan pada penelitian ini mencakup beberapa kegiatan yang akan dan mungkin dilakukan oleh siswa pada saat penelitian berlangsung.

Data hasil observasi akan dikelompokan dan dianalisis berdasarkan aspeknya untuk tiap siklus dengan teknik analisis deskriptif dan dilihat perkembangannya tiap pertemuan, apakah sudah mencapai indikator yang diharapkan. Pada siklus 1 akan dianalisis tingkah laku serta pretasi belajar siswa pada KD 4.6, 4,7. Indentifikasi Pengantar Administrasi Perkantoran , dengan Model Pembelajaran Kooperatif Tipe Presentasi.

Tanpa penguatan pada siklus 2 akan dianalisis tingkah laku serta prestasi belajar siswa pada KD4.6 dan 4.7, dengan penguatan.

\section{Hasil Pengamatan Siklus}

Pengamatan pada siklus 1 yang dilakukan pada saat proses belajar mengajar yang dilakukan selama dua minggu meliputi keaktifan, dankebiasaan sikap negative siswa. Adapun pemahaman konsep siswa diperoleh dengan memeriksa jawaban hasil post test setelah pembelajaran selesai, yaitu pada minggu ke tiga.

Berikut di bawah ini adalah hasil pengamatan tingkah laku dan hasil post test yang dilakukan siswa pada siklus 1 dan 2.

\section{Refleksi Siklus}

Dari hasil observasi pada siklus 1, peneliti menemukan keberhasilan dan kegagalan dari tindakan yang diberikan, pada tahap awal pembelajaran masih ada siswa yang tidak perhatian terhadap proses pembelajaran, yaitu adanya siswa yang ngobrol dan jalan-jalan ke kelompok lain, tetapi setelah diberi pengertian bahwa setiap siswa harus aktif menjawab pertanyaan dalam LKS maka pada pertemuan kedua mereka sudah tidak melakukannya lagi .

Dapat dianalisis bahwa penyebab utama kekurangan dalam mencapai indikator tersebut adalah mereka walaupun sudah berdiskusi dan menjawab pertanyaan- Observasi yang dilakukan sama seperti yang dilakukan pada siklus 1,yaitu keaktifan ,kehadiran, kebiasaan, dan jawaban post test siswa. Keaktifan Siswa dapat 
dilihat pada table berikut ini Hasil Observasi ini menunjukkan bahwa sebagian besar siswa berusaha aktif membaca dan berdiskusi, baik pada tahap berpasangan maupun diskusikelompok dan diskusi kelas. Rata-rata siswa aktif adalah $=90 \%$. Dari siswa yang mengikuti postest. Kehadiran Siswa setelah dua kali pertemuan maka pada pertemuan ke 3 peneliti memberikan post test yang bertujuan untuk mengetahui seberapa

Dari table nilai hasil post test pada siklus 2 di atas, dapat dilihat bahwa nilai post test siswa sudah mencapai indikator yang diharapkan yakni jumlah siswa yang mencapai ketuntasan yaitu 37orang dari total jumlah siswa 34 orang Pada siklus ke 2 ini peneliti melihat bahwa pelaksanaan model pembelajaran Kooperatif tipe Presentasi telah dapat meningkatkan prestasi belajar siswa, dan mencapai indikator penelitian yang ditetapkan yakni persentase siswa yang mencapainilai tuntas adalah 98,43.

\section{DIAGRAM}

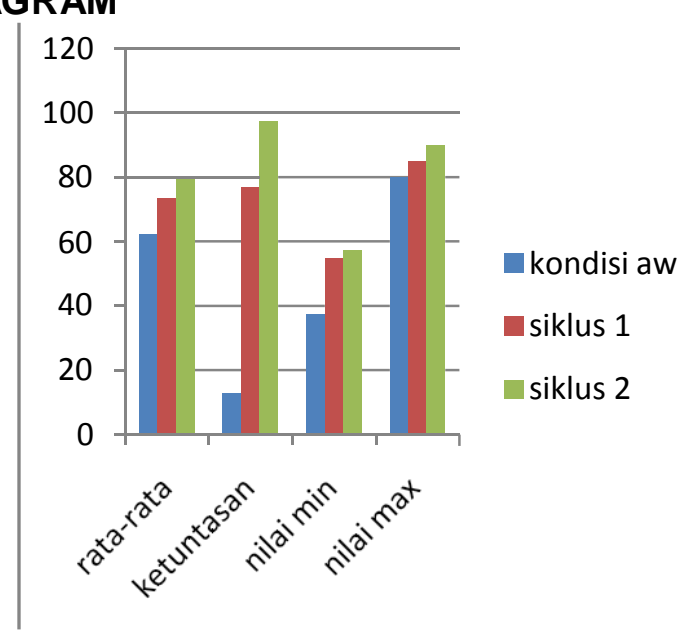

\section{Kesimpulan}

Dari hasil penelitian tindakan kelas tentang penggunaan metode ,model kooperatif tipe presentasi ini dapat disimpulkan sebagai berikut :Dengan penerapan metode kooperatif tipe presentasi pada pembelajaran Pengantar Administrasi Perkantoran dapat meningkatkan motivasi siswa untuk menpraktekkan tata cara berkomunikasi dalam kantor dan menata ruang kantorsiswa kelas $\mathrm{X} A \mathrm{P}$ 1.di SMK Negeri 48 Jakarta. Hal ini dapat terlihat dari hasil penelitian, terjadi peningkatan disiklus 1 ke siklus 2

Berdasarkan hasil penelitian, diperoleh bahwa terjadi peningkatan nilai hasil belajar sebagai berikut :
Dari kondisi awal ke Siklus 1, rata-rata nilai 73,25 menjadi 85,27.

Dari siklus 1 ke siklus 2, rata-rata nilai 85,27 menjadi 96,42 . Persentase jumlah siswa yang mencapai nilai Kriteria Ketuntasan Minimum, meningkat yaitu: Dari kondisi awal ke Siklus 1, yaitu $11,25 \%$ menjadi $86,92 \%$. Dari siklus 1 ke siklus 2, yaitu $87,92 \%$ menjadi $98,43 \%$. Ternyata pembelajaran dengan Model Kooperatif Tipe Presentasi dapat meningkatkan prestasi belajar Pengantar Administrasi Perkantoran dalam aspek pemahaman konsep dan Praktek. Aspek yang kedua adalah keaktifan siswa mengikuti proses pembelajaran meningkat dari $75,51 \%$ menjadi 87,62 $\%$.

Aspek yang terakhir adalah kebiasaan negative siswa berkurang dari $5,15 \%$ menjadi $0,77 \%$. Dengan demikian model pembelajaran Kooperatip Tipe Jigsaw ini selain dapat meningkatkan prestasi nilai hasil belajar juga dapat mendorong siswa untuk meningkatkan aktivitas pembelajaran yang positif dan menurunkan kebiasaan buruk pada saat proses pembelajaran yang jelas pada siswa melalui metode pembelajaran agar hasil pembelajaran sesuai yang diharapkan. Guru sebagai pendidik harus memiliki kreativitas yang tinggi untuk mencari berbagai terobosan baru agar kegiatan pembelajaran di kelas lebih bervariasi dan dapat meningkatkan motivasi belajar siswa

\section{DAFTAR PUSTAKA}

Ausubel, David P.1968. Educational Psicology, New York : Rine Hart.Pub Co.

Eggen dan Kauchak.1993. Teori Belajar -Kooperatif html.27-04-2012.

Ibrahim M,F. Rachmadiarti, M. Nur, dan Ismanto, 2000. Pembelajaran Kooperatif. Surabaya :UNESA Universyti Press.

Peraturan Pemerintah Republik Indonesia No 19 tahun 2005 Tentang , Standar Nasional Pendidikan.

Supardi Suharjono, P 2009. Strategi Menyusun Penelitian Tindakan Kelas, Yogyakarta, Andi Offset.

Supardi, P 2009. Publikasi IImiah Non Penelitian dalam Pengembangan Kepropesian Berkelanjutan Bagi Guru.Yogyakarta, Andi Offset.

Wahana pendidikan, Edisi 2 Tahun 2012, Jurnal Pendidikan, Wahana 
Pendidikan, Jakarta, Wahana Pendidikan .

Winarno Surakhmad , Prof.Dr. 1982,

Pengantar Interaksi mengajar

Belajar Dasar dan Teknik Metodologi Pengajaran, Bandung: Tarsito.

Slavin, Robert E.1955, Cooveratif Learning - Theory, research, and practise, Borton : Allyn and Bacon.

Atmosudirdjo , Prayudi, 1982.

Kesekretarisan dan Administrasi Perkantoran , Jakarta, Galia Indonesia. 